\title{
Climate change mitigation: a role for climate clubs?
}

\author{
Jon Hovi ${ }^{1}$, Detlef F Sprinz ${ }^{2,3}$, Håkon Sælen ${ }^{1,4}$ and Arild Underdal ${ }^{1,4}$
}

\begin{abstract}
The limited success of the UNFCCC negotiations has enticed scholars, environmentalists, and policymakers alike to propose alternative approaches to climate cooperation. This article reviews the scholarly literature concerning one such proposed alternativeclimate clubs. According to the club approach, it would be promising to start with small groups of "enthusiastic" countries. These countries would outline what they are willing and able to do, conditional on what other enthusiastic countries offer and implement. Moreover, these enthusiastic countries would try to entice "reluctant" countries to join via "exclusive and contingent" measures. Focusing on the conditions for a climate club to effectively reduce global emissions, we organize our review around four main questions: first, what is a climate club's potential for providing benefits that accrue exclusively to club members? Second, how might leadership influence a climate club's ability to eventually become effective? Third, what insights can the formal modelling literature offer concerning the effectiveness of climate clubs? Finally, which is the empirical record of existing climate clubs? We conclude by providing several suggestions for future research.
\end{abstract}

\section{Background, aims and plan}

$\mathrm{t}$ is fair to say that the global negotiations under the United Nations Framework Convention on Climate Change (UNFCCC) have failed to produce an effective agreement. Following Hovi et al. (2013), an agreement is here said to be effective if it substantially reduces global emissions directly in the agreement's own lifetime or indirectly by paving the way for a future agreement that substantially reduces global emissions directly.

To substantially reduce global emissions (directly), an agreement must attract broad participation among major emitters, obligate the participating countries to cut their emissions considerably and achieve high compliance rates. Notably, an agreement cannot be effective unless it meets all of these three requirements (Barrett, 2003).

Even though this effectiveness criterion is not particularly precise, it is clear that existing UNFCCC agreements fall well short of meeting it. The 1992 Framework Convention provided no binding targets for emissions reductions. Kyoto 1 (2008-2012) suffered from significant shortcomings concerning participation (only 37 countries participated with binding emission targets) and ambition level (these 37 countries, responsible for around $20 \%$ of global emissions, were only committed to reducing their emissions by approximately 5\% below 1990 levels).

\footnotetext{
${ }^{1}$ Department of Political Science, University of Oslo, Oslo, Norway ${ }^{2}$ PIK-Potsdam Institute of Climate Research, Potsdam, Germany ${ }^{3}$ Department of Economic and Social Sciences, University of Potsdam, Potsdam, Germany ${ }^{4}$ Cicero-Centre of International Climate and Environmental Research-Oslo, Norway
} 
A series of withdrawals before and immediately after 2012 (when Kyoto 1 expired) entailed even more limited participation in Kyoto 2 (2013-2020).

The UNFCCC, Kyoto 1 and Kyoto 2 have likely caused global emissions to become (somewhat) lower than what they would have been otherwise. However, they do not come close to solving the climate change problem-individually or collectively. Indeed, by the time of the 2015 Paris climate meeting, global emissions were higher than ever before.

The Paris agreement achieved a sharp increase in the number of parties with an emissions reduction commitment. However, it contains no enforcement measures; indeed, the emissions reduction commitments are not even legally binding. It thus remains an open question whether Paris will be significantly more effective than its predecessors.

The limited success of the UNFCCC negotiations has enticed scholars, environmentalists and policymakers alike to propose alternative approaches to climate cooperation. In this article, we review the scholarly literature concerning one such proposed alternative-climate clubs. According to the club approach, it would be more promising to start with small groups of "enthusiastic" countries. These countries would outline what they are willing and able to do, conditional on what other enthusiastic countries offer and implement. Moreover, these enthusiastic countries would try to entice "reluctant" countries to join via "exclusive and contingent" measures (Victor, 2011).

Falkner (2015) argues that starting small may be advantageous in at least three ways-by facilitating dialogue and bargaining, by creating incentives for membership, and by offering great powers a privileged position (thereby making the climate regime more legitimate in their eyes). ${ }^{1}$ Concentrating on the second way (the incentives for membership), we focus on how enthusiastic countries might induce reluctant countries to become members, while pursuing high ambitions for emissions reductions.

We conceptualize enthusiastic countries as countries willing to undertake emissions reductions beyond what maximizes their material self-interest. For the purposes of this article, it is of lesser importance whether such enthusiasm originates in altruism, ${ }^{2}$ in some kind of ideological conviction or in yet another source.

Climate cooperation in small groups already takes place; however, the emissions reductions achieved by such existing groups have thus far been insignificant. Scholars are therefore trying to reach a better understanding of the conditions under which future small-group efforts might be more successful.

The purpose of this article is to review important contributions to the literature on climate clubs. Specifically, we review the scholarly literature analysing the conditions under which a group that is initially small-and thus quite ineffective in reducing global emissions-might attract more members while maintaining a high ambition level, so that it becomes more effective. A very successful climate club could-by creating a snowball effect-eventually come to include all UNFCCC countries.

We proceed in the following manner. The next section provides a definition of climate clubs and relates the concept of a climate club to classical club theory. The section after that considers the potential of climate clubs for providing benefits that accrue exclusively to club members. The following section focuses on how leadership may influence a climate club's ability to eventually become effective. Drawing on two recent papers we have written on the subject, the subsequent section summarizes recent results from the formal modelling literature on climate clubs. The penultimate section evaluates the empirical record of climate clubs. The last section provides some final remarks and suggestions for future research.

\section{The nature of climate clubs}

In this section, we first offer a definition of climate clubs and then relate the scholarship on climate clubs to the more general literature on clubs. ${ }^{3}$

Defining climate clubs. We define a climate club as any international actor group that (1) starts with fewer members than the UNFCCC has and (2) aims to cooperate on one or more climatechange-related activities, notably mitigation, adaptation, climate engineering or climate compensation.

While according to this definition, a climate club could also cooperate on adaptation, climate engineering, or climate compensation, we here consider only cooperation concerning mitigation. Moreover, although a climate change mitigation club could contribute to mitigation both inside and outside the UNFCCC, we focus in this article on the possibility that a climate change mitigation club might offer an alternative or a supplement to UNFCCC agreements. ${ }^{4}$

Depending on who the members are, the mitigation effort of a small group will typically have only limited impact on global emissions. Key factors for making a climate change mitigation club effective include the club's ability to (1) provide a viable basis for cooperation among enthusiastic countries, (2) attract new members and (3) ensure that new and existing members alike contribute with considerable emissions reductions. Considerable emissions reductions are costly; hence, reluctant countries have an incentive to free ride by remaining non-members. To be able to grow and eventually become effective (in the sense of substantially reducing global emissions), a climate club must find ways to offset the incentive to free ride.

Relation to the general literature on clubs. As emphasized by Cornes and Sandler (1986), the origins of club theory can be traced at least back to Pigou (1920) and Knight (1924). These early contributions were concerned with identifying optimal tolls for constraining traffic on a congested road, assuming that a less attractive alternative road exists. They essentially tried to identify the optimal size of a club (that is, the club consisting of the drivers on the more attractive road).

Buchanan (1965) remains one of the most influential scholars on club theory. He defines a club as a member-owned institutional arrangement aiming to provide a "club good". In Buchanan's terminology, a club good is an excludable good that exhibits little or no rivalness for low to moderate consumption levels but significant rivalness for higher consumption levels because of congestion effects. Buchanan studied the conditions under which such goods will be provided, what the optimal club size is (given the presence of congestion effects), and how provision conditions interact with optimal-size conditions.

Other influential early contributions include work by Tiebout (1956), Wiseman (1957) and Olson (1965). ${ }^{5}$ Tiebout (1956) suggested a "voting-with-the-feet" hypothesis, stating that a population will tend to partition itself among jurisdictions (or clubs) to match individuals' preferences for local public goods and taxation options. In contrast, Wiseman (1957) formulated a club principle for sharing the costs of a public utility among the users. Finally, Olson (1965) introduced the notion of exclusive groups while analysing the production of impure public goods.

Important to note is that including all these contributions under the rubric of club theory requires a rather broad definition of clubs. In particular, Buchanan (1965) was concerned with what he termed club goods (excludable and non-rival up to a point). In contrast, Wiseman (1957) focused on private goods (excludable and rival), whereas Olson (1965) studied what he termed "exclusive" collective (or public) goods, which are currently more 
Table 1 | Types of goods and different contributions to club theory

\begin{tabular}{|c|c|c|}
\hline & Rival & Non-rival \\
\hline Excludable & Private goods (Wiseman) & Club goods (in the narrow sense) (Buchanan) \\
\hline Non-excludable & Common pool goods (Olson) & Public goods (Climate clubs) ${ }^{a}$ \\
\hline
\end{tabular}

often referred to as common pool goods (non-excludable and rival; see Ostrom et al., 1994: 7). What these scholars have in common is that they all focused on goods provision in groups of (more or less) limited size. The differences between these contributions and climate clubs in terms of their (main) focus may be illustrated as shown in Table 1 .

Following these path-breaking contributions, a substantial body of research on club theory has developed. For example, scholars have considered whether and how club formation and optimality conditions are influenced by heterogeneous populations (for example, Fraser and Hollander, 1992), transaction and exclusion costs (for example, Helsley and Strange, 1991), and uncertain use because of capacity constraints (for example, Sandler et al., 1985).

Prakash and Potoski (2007) draw a useful distinction between two types of clubs. ${ }^{6}$ In "Buchanan clubs", the production and allocation of club goods constitute the primary goals; indeed, such production and allocation are goals in themselves. For example, a tennis club's primary goals are to provide required facilities for its tennis-playing members and to allocate playing times. By contrast, in "voluntary clubs" the main goal is to produce a public good or some other benefit that generates a positive externality.

This distinction is crucial. In a Buchanan club, no incentive for free riding exists, because only those who pay the club fee can enjoy the benefits. By contrast, in a voluntary club strong incentives for free riding may exist. Voluntary clubs, therefore, must offer excludable benefits for encouraging membership and for inducing members to contribute more to the production of a public good (or some other benefit that entails a positive externality) than they would do as non-members. In the literature on climate clubs, such excludable benefits are usually referred to as club goods. We call them "club goods in the wide sense", to distinguish them from the type of goods Buchanan had in mind (club goods in the narrow sense).

The notion of club goods used in the climate club literature is thus broader than Buchanan's. In particular, the notion of club goods used in the climate club literature comprises not only goods that entail a congestion effect (at some point), but also goods without such a congestion effect and even goods that become more beneficial with increasing participation. Indeed, some of the contributions reviewed in this article consider club goods that scale up with club size. ${ }^{7}$

A climate change mitigation club (henceforth "climate club") may be considered as a subset of voluntary clubs. It aims to induce countries to undertake mitigation (which entails a positive externality) beyond what UNFCCC agreements require. Moreover, it provides incentives to curb free riding.

A well-known barrier for progress in the UNFCCC negotiations is, absent a change in procedures, the consensus rule. This rule provides a veto to the least enthusiastic party (or at least to the least enthusiastic major party (Underdal, 1980; Underdal, 1998; but see Hovi and Sprinz, 2006). To bypass this barrier, Victor (2011) suggests that cooperation should begin with small groups (that is, clubs) consisting of enthusiastic countries. These groups should aim for agreements with a high degree of flexibility concerning the choice of policy strategies. They should also focus on policies that governments actually control, rather than on emission levels (which are only partly under governmental control). The "backbone" of Victor's proposal is a series of contingent offers, whereby governments outline what they are "willing and able to do", depending on what others offer and implement (Victor, 2011: 23). We will refer to such contingent offers as conditional commitments. Finally, reluctant countries should be enticed to join via "exclusive and contingent" measures-club goods or what Olson (1965) refers to as "selective incentives" - such as preferential market access for club members.

We should mention that not all scholars adhere to a definition of climate clubs that resembles ours. For example, Stewart et al. (2013a, b) conceive of climate clubs as Buchanan clubs, where non-climate co-benefits provide the primary or even the sole incentive for participation. ${ }^{8}$ Suggested club benefits include harmonization of technical standards, collaborative $\mathrm{R} \& \mathrm{D}$ on renewable energy and reduced mitigation costs, as well as other benefits derived from the linking of emissions trading schemes. An interesting feature of their work is that they propose to broaden the membership beyond states, a point we return to in the final section.

\section{The use of club goods}

As already mentioned, the provision of club goods constitutes an important instrument for inducing club growth. A club good (in the wide sense) can be provided to members while being denied to non-members at little or no cost. Hence, in a climate club, the provision of a club good creates private incentives for accepting the club's mitigation requirements. These private incentives come in addition to the (rather limited) incentives of reduced climate damages resulting from mitigation.

Because the club good must lie outside the sphere of direct greenhouse gas mitigation benefits, providing it to the members of a climate club will involve issue linkage. ${ }^{9}$ It is well known that linking cooperation on two or more issues can result in a Pareto-superior outcome, as compared with treating each issue separately.

No credible climate club exists as of yet; hence, we cannot draw on actual experience. Instead, we highlight the potential benefits and drawbacks of using club goods to enhance cooperation in a climate club.

Some scholars find that linkage to technology R\&D can advance climate cooperation (Carraro and Siniscalco, 1997; Buchner et al., 2005). Questioning these findings, Barrett (2003) argues that several international agreements (including the Montreal Protocol) require the parties to cooperate on technology R\&D. Yet these agreements do not encourage members to withhold the fruits of such R\&D from non-members. A likely reason, he argues, is that doing so would be detrimental to the members' self-interest. Similarly, linkage of climate cooperation to trade has been proposed, yet has also been dismissed as detrimental to members' self-interest (Barrett, 2003). In practice, however, countries sometimes seem prepared to accept losses from imposing trade sanctions-particularly when they believe sanctions might serve a sufficiently important purpose. Making the assumption that enthusiastic actors might be prepared to 
forgo potential trade benefits should reluctant actors decline to join the club seems fully consistent with Victor's (2011) basic idea of enthusiasm.

Victor (2011) suggests a range of member-only benefits including a low-tariff zone for low-emission technologies, international linkage of properly designed emissions trading systems ${ }^{10}$ and border tax adjustments to combat leakage (that is, the movement of pollution-intensive production abroad). Border tax adjustments enable club members to protect domestic producers exposed to stringent environmental production standards from competitors that are not obliged to abide by these (or equivalent) standards. Border tax adjustments offer various members-only benefits: protection from the cost advantage of imports from less environmentally inclined producers, export subsidies when exporting goods and services to areas with lower environmental standards, and clear accounting rules for the differential costs involved between different environmental standards. Border tax adjustments thus provide incentives for companies to favour higher environmental standards, while not being disadvantaged in international trade compared with competitors from jurisdictions with lower environmental standards.

Environmental club goods are also conceivable. For example, technology-sharing clubs along the lines of the effort currently emerging between California and India on soot control (Pachauri et al., 2014) might assist countries in tackling air pollution, with benefits largely restricted to club members (Victor, 2015).

Reputation effects, too, might serve as a club good. In particular, reluctant countries might choose to join a climate club if membership entails reputational benefits that outweigh the cost of meeting the club's mitigation requirement (Prakash and Potoski, 2007; Green, 2015). ${ }^{11}$

Moreover, proposing an Arctic black carbon club for shipping, Brewer (2015) suggests that participation might be incentivized by restricting the right to operate in Arctic waters to ships meeting club standards for equipment and operation. While this system could plausibly provide incentives to participate in a club of ship-owners, it is less clear how it could motivate participation in a club of countries. Without a club of countries (or a treaty) as a basis, it is difficult to see how access to the Arctic could be restricted in the first place.

Border measures have so far yet to be enacted, despite that such measures have been included in draft US legislation and have been threatened by the European Union (EU). Perhaps the most enticing suggestions are cooperation on technology strategies and technology pools (Rossi, 2014), that is, government-togovernment or public-private partnerships fostering lowgreenhouse-gas technologies by risk-sharing, pooling and common rules concerning intellectual property rights (for example, patent pools).

It is not inconceivable that cooperation on low-emission technologies might be feasible; however, such technologies can also be crucial to national exports and growth strategies, thereby creating a reverse incentive for not sharing intellectual property rights following the basic research phase. Furthermore, most lowgreenhouse-gas technologies can be developed by a single major country (at least in the OECD area) or by a multinational corporation. Finally, technology development undertaken at the national level or within a multinational corporation (MNC) would reduce transaction costs, so that only technologies with highly uncertain potential outcomes and high absolute costs would remain as suitable candidates. If costs are low, a country or MNC could develop low-greenhouse-gas technologies themselves and make the results available under a commons licence, thereby reaping audience benefits with its electorate or other target groups.

During the past decade, enthusiasm for further expanding cooperation on international trade has waned. However, the international WTO/GATT trading system remains a very potent potential agent for issue linkage between environmental goals and manifest private benefits from international trade. A core element of the WTO/GATT system is the most-favored-nation (MFN) principle, which states that benefits offered to one member must be granted to all members without discrimination. The proposal of a WTO Environmental Good Agreement for tariff reductions among initially 14 members (including the EU) might serve as an example of how to start incrementally (Leycegu and Rammirez, 2015). An exception to WTO rules could be predicated on the precedent of three major exemptions from the MFN principle, namely GATT Article XX(g), which opens for exceptions to MFN in relation to natural resource conservation; GATT Article XXIV, which allows the creation of free trade zones or customs unions that increase internal trade more than they divert global trade; and the Enabling Clause (Decision on Differential and More Favorable Treatment Reciprocity and Fuller Participation of Developing Countries), which permits developing countries to prioritize development over trade while remaining members of the WTO.

Overall, border tax adjustments and issue linkage (especially with international trade) offer opportunities to create memberonly incentives which increase the probability of climate clubs to come into being and to grow over time.

\section{Leadership in founding climate clubs}

We now turn to two questions pertaining primarily to the initial stage of club formation. First, what characterizes the most likely initiator(s) or founder(s) of a climate club? Second, given these characteristics, what mode(s) of leadership can these initiators provide in recruiting new members and enhancing club performance? Since our strict definition of climate clubs leaves us with virtually no empirical evidence to build on, we approach these questions by relying mainly on theoretical reasoning and results obtained through agent-based modelling and other types of simulations.

What characterizes likely club initiators? For a rational actor to voluntarily engage in a joint project, it must expect-with sufficient confidence-to reap net benefits from its own involvement. Similarly, for a country to initiate (or participate in initiating) the formation of a climate club, it must expect this club to generate net private benefits that the country could not have obtained through unilateral efforts or through some other international arrangement (notably, UNFCCC global conference diplomacy).

What, then, characterizes countries likely to be able to reach net private benefits from climate club initiation? The answer will to some extent depend on countries' motivational orientations. Assume, first, that we are dealing with countries motivated exclusively by (material) self-interest. Given this assumption, the most likely initiators will be found among countries combining relatively high vulnerability to climate change with relatively inexpensive options for reducing own involvement in these activities. In the terminology of environmental economics, this profile could be described as a combination of high damage costs and low abatement costs (Sprinz and Vaahtoranta, 1994).

Vulnerability to climate change can be caused by circumstances ranging from the intensity and frequency of natural disasters such as flooding, droughts or extreme heat waves, to socio-economic and political properties, such as poverty, and weak or repressive systems of governance. Vulnerability estimates should include also negative side-effects of damage suffered by others; for example, costs of accommodating increasing immigration triggered by deteriorating living conditions elsewhere. 
Similarly, opportunities for cutting one's own GHG emissions depend mainly on the role of fossil fuels in the present energy mix, the size of cost-competitive renewable energy resource endowments (measured in per capita terms), and technological and economic potentials for increasing energy efficiency.

Moreover, other things being equal, the higher a country's share of global GHG emissions, the larger the impact of its own mitigation efforts on the climate. For this reason, a large and vulnerable emitter has stronger incentives to behave "responsibly" in providing a (global) collective good than a smaller and less vulnerable emitter has.

Assume, now, that likely club initiators acknowledge responsibility also for the welfare of others. More precisely, assume that this acknowledgement pertains specifically to groups that are (1) expected to be more vulnerable to climate change than the initiator itself is, and (2) "disenfranchised" in the sense of having no access to climate policy decision-making that may critically affect their quality of life. Two large and heterogeneous groups meet both of these criteria: (1) future generations and (2) the hundreds of millions of people presently living in deep poverty, caused in part by discrimination and other forms of repression. Acknowledgement of responsibility for future generations may be expected to materialize in the form of longer-term policy perspectives, changing the cost-benefit calculus in favour of more precautionary mitigation. Acknowledging responsibility for the poor and repressed will likely involve active support for applying basic principles of human rights and distributive fairness to international cooperation. A genuine commitment to these principles will shift the cost-benefit calculus in the direction of higher willingness to engage in mitigation efforts and probably also more funding for adaptation.

To be able to establish a proper club, an initiator will need one or more partners. An ideal partner should score high on at least two criteria. First, and most importantly, it should share the initiator's interest in developing and implementing more ambitious and effective GHG mitigation programmes and its acknowledgement of responsibility also for the welfare of vulnerable others. Similar preferences and norms are important in facilitating agreement on club statutes and more generally in expanding the settlement range. Second, an ideal partner should also be in a position to help attract one or more other countries that could further strengthen the club by joining.

The ability to attract additional club members depends, in part, on the level and scope of economic interdependence between the "founding" partners and other potential club members, as well as any formal or informal leader-follower relationships that may exist between the two sides (think of, for example, India's role in mobilizing and speaking for the G-77). Here, too, size measured in terms of (potential) partners' shares of total GHG emissions enters the equation, in most cases probably confirming Olson's (1965: 29) hypothesis that "[W]here small groups with common interests are concerned [...], there is a systematic tendency for 'exploitation' of the great by the small". Should a club grow to achieve truly transformative cuts in emissions, however, some of the small and most vulnerable countries may see new hope of avoiding disaster and therefore respond by increasing their own mitigation efforts to reinforce the moral imperative for major emitters to uphold and deepen their emissions reductions. ${ }^{12}$

Recruiting new members constitutes an exercise in leadership. As described above, the most important type of leadership at the club formation stage is what Young (1991: 288) labels the "structural" mode, defined as "... translating the possession of material resources into bargaining leverage". ${ }^{13}$ Because structural leadership is based on one actor's control over goods or events important to others, it is a type of leadership that can best be provided by an actor combining a predominant position within the issue area in focus with a high score on an overall power index (Underdal, 1994: 187). Young (1991) explores also two other types of leadership to which also (representatives of) smaller states may sometimes aspire. One of these types"entrepreneurial" leadership-consists essentially of contributions to integrating partly divergent preferences into an exchange of conditional commitments beneficial to both or all parties. The other type- "intellectual" leadership-relies on the power of knowledge and ideas to help the parties understand the challenge they face and see for themselves how their interests and concerns can be constructively addressed through cooperative arrangements. All these modes of leadership can be important to the success of climate clubs. At the founding stage, however, control over goods or events important to prospective partners seems to be the critical asset. And since "structural" leadership can be provided only by powerful actors, the pivotal founding members will most likely be found among countries with large economies and high GHG emissions.

\section{The emergence of effective climate clubs: some lessons from formal models}

Under what conditions (if any) might effective climate clubs emerge? Formal models constitute useful tools for answering this question; however, not many formal models have so far been developed to specifically analyse climate clubs. We therefore look also to related strands of research.

One such related strand consists of game-theoretic work on multiple coalitions. A general finding from this literature is that total mitigation becomes higher when multiple coalitions are allowed to form than when the number of coalitions is exogenously limited to one (Carraro, 1999; Finus and Rundshagen, 2003; Asheim et al., 2006; Finus et al., 2006; Hannam et al., 2015). A second finding is, however, that even with more than one coalition, the outcome typically remains (highly) inefficient.

These contributions typically consider the conditions under which multiple coalitions might be externally and internally stable or can be part of a renegotiation-proof equilibrium in a repeated game. In contrast, they have mostly little to say about the conditions under which clubs might emerge and grow over time. An interesting exception is Weikard (2011), who uses a twostage coalition model with multiple rounds to consider how a climate agreement with broad participation might develop in a bottom-up fashion. In his model, countries that have not yet joined by round $j$ gets another chance to join in round $j+1$, whereas countries having joined in or before round $j$ act as a single large player in round $j+1$. A crucial-but rather strongassumption in Weikard's model is that accession to the agreement entails an irrevocable commitment that makes withdrawal impossible.

A second related strand comprises leader-follower models. Such models consider how followers are likely to respond to a leader taking unconditional or conditional action. Unconditional action by a leader typically has zero or even adverse effect on followers' emissions reductions (Hoel, 1991; Buchholz et al., 1998). In contrast, conditional action can contribute positively under some circumstances (Underdal et al., 2012; Holtsmark, 2013).

A few studies use a formal model specifically to map the conditions for the emergence and growth of climate clubs. Hovi et al. (2015) and Sælen (2015) apply a novel agent-based model of a climate club that starts out with a small number of "enthusiastic actors" seeking to incentivize "reluctant" actors to join. The model's basic logic follows the ideas laid out by Victor (2011). Unlike Weikard's (2011) model, our model permits any club member to withdraw (like Canada did from Kyoto). 
As far as we know, this model is the only existing agent-based model specifically focusing on conditions for a climate club's emergence and growth. We therefore review in some detail the two papers written on the basis of this model.

Our model considers one specific conception of a climate club, which requires each member to spend $1 \%$ of its GDP on mitigation. The baseline model assumes that if all countries were to become members, the present value of global damage costs would be reduced by $3 \%$ of gross global product (GGP). These figures are very rough estimates of the costs and benefits of effective global action on climate change. Alternative assumptions are considered for sensitivity analyses.

The model's actors represent the world's countries. The model includes empirically grounded values concerning GDP, climate emissions, population, and vulnerability to climate change. The actors are of two types, depending on their motivation for mitigation. Reluctant actors are assumed to be rational and selfinterested; hence, they will join the club if and only if joining leads to private benefits that exceed the abatement costs associated with becoming a member (in the model, these abatement costs equal $1 \%$ of the country's GDP). As defined by Victor, enthusiastic actors are willing to spend their own resources on mitigation. We assume they have an exogenous motivation to start a club, irrespective of (initial) costs. They are, in other words, willing to incur mitigation costs of $1 \%$ of GDP even without any commitment by reluctant parties to follow suit. However, one limitation is placed on their enthusiasm: Even an enthusiastic actor will exit if the club-having conducted negotiations with all reluctant actors-proves to generate less net private benefits for the enthusiastic actor concerned than the noclub scenario does.

Three categories of conditions vary across our simulation runs. First, we consider different constellations of enthusiastic actors: the three largest emitters (China, the United States, the EU) individually; every possible combination of these three biggest emitters; the BASIC ${ }^{14}$ group; and the BRICS ${ }^{15}$ group. Second, we test different instruments for incentivizing reluctant countries to join. Hovi et al. (2015) explore the effect of club goods and conditional commitments, that is, pledges made by club members to deepen their mitigation commitments if others join. In contrast, Sælen (2015) focuses on the effect of side payments. Finally, the model makes several auxiliary assumptions concerning factors such as the size and distribution of damage costs avoided, and we test the effect of modifying these assumptions through sensitivity analyses.

Our results suggest that a small group consisting of the "right" enthusiastic actors (in some cases even a single actor) might, by properly incentivizing others, be able to facilitate effective global action. Moreover, clubs covering a substantial share of global emissions arise under a broad set of assumptions. Finally, all of the three instruments mentioned above (club goods, conditional commitments and side payments) have at least some potential for incentivizing reluctant actors to join.

Different incentives and their effect on club growth. If a climate club can offer sizeable exclusive benefits, its prospects for growth are bright. For exclusive benefits comparable in size to those estimated for the transatlantic trade and investment agreement currently being discussed by the EU and the United States, the model predicts that all except one of the coalitions we consider would achieve considerable success. ${ }^{16}$ Indeed, the club would eventually include enough large emitters to control between one third and two thirds of global emissions.

In the baseline model, conditional mitigation commitments-if used alone-are typically ineffective, with the notable exception that they enable a coalition consisting of the United States and the EU to induce China to join. However, in scenarios with higher global returns from cooperation (in the form of climate damage costs averted), conditional commitments facilitate clubs comprising up to $50 \%$ of global emissions, producing global benefits (in terms of climate impacts avoided) worth around 2-3\% of GGP.

Our results suggest that the combination of conditional commitments and a club good is highly conducive for fostering effective climate clubs. Even with only moderate club-good benefits, adding a conditional-commitment option increases participation in all the clubs we modelled. In many cases, clubs end up covering around $80 \%$ of global emissions. Furthermore, the extra mitigation following from implemented conditional commitments entails a deepening of cooperation.

Side payments appear particularly effective for attracting members. One reason for their relative effectiveness is that side payments accrue to potential entrants only. In contrast, a clubgood benefits all members, whereas conditional mitigation efforts benefit members and non-members alike. Our results indicate that the EU alone or the United States alone could finance a club able to grow to cover more than $50 \%$ of global emissions. We estimate that doing so would cost US\$ 60-70 billion annually, or $0.3-0.4 \%$ of EU or US GDP.

If new members join the initiators in contributing to subsequent side payments, very large clubs often result. Disallowing regressive side payments (from a poorer country to a richer country) reduces the scope of some clubs, yet does not render side payments ineffective. The global sum of required payments ranges from tens to hundreds of US\$ billion annually. Generally, the sums are comparable to the US\$ 100 billion goal enshrined in the Copenhagen Accord (UNFCCC, 2009) and reaffirmed at COP 21 at Paris in 2015. Recipients of the largest absolute payments are typically emerging economies, while small countries receive the largest sums relative to their own GDP. Rich countries with low carbon intensities are the hardest to recruit through side payments, regardless of whether fairness constraints are imposed.

While broad participation (measured as the club members' share of global emissions) is achieved under a variety of conditions, universal participation is achieved only under conditions that appear rather unrealistic. For example, a universal club arises only under very optimistic assumptions concerning the size of the club-good benefit. If such a benign benefit scale is chosen, the trade benefits from a model club consisting of the EU and the United States exceeds, by about 50\%, the expected benefits from the transatlantic trade and investment agreement mentioned earlier.

Universal participation arises also under a scenario with unconstrained side payments, that is, a scenario where all club members, including those that were initially paid to join, contribute to funding side payments. Unconstrained side payments imply, among other things, that poor countries may pay richer countries to participate. In practice, fairness considerations will likely rule out such transfers.

Other factors influencing club emergence and growth. Across all instruments, the likelihood of joining is an increasing function of vulnerability to climate-change impacts, as would be expected on the basis of a simple cost-benefit calculus. The effect of vulnerability is, however, overshadowed by the effect of other actor attributes. Which attribute dominates depends on which incentives the club uses to attract members. When conditional commitments and club-good benefits are used, emission size has the largest effect on the likelihood of joining (that is, large emitters are most likely to join). When side payments are used, actors with high emission intensities (emissions per unit of GDP) are most likely to join. 
Our simulations suggest that a club's success is an increasing function of the returns to cooperation, that is, of the damage costs that can be avoided through mitigation. Worth noting is that this result, while quite intuitive, contradicts certain gametheoretic predictions concerning treaty participation (see, for example, Barrett, 2003, Chapter 7). In our model, increasing the returns from cooperation (avoided damage) has a particularly large influence on the effectiveness of conditional commitments.

Our simulations also suggest that the asymmetric distributions of GDP and of emissions constitute key factors for explaining a club's success. A model with homogenous actors generates drastically less optimistic results. ${ }^{17}$ This finding suggests that incorporating real-world asymmetries may be essential for formal models to provide relevant insights. This being said, we should add that heterogeneity concerning climate change vulnerability has no systematic effect on a club's effectiveness. However, it does influence which actors become members and how abatement costs are shared.

\section{The empirical record of climate clubs and club-like arrangements}

A few scholars have assessed the empirical record of actor groups trying to address climate change outside the UNFCCC. Most of these actor groups do not qualify as clubs in the strict sense of the theoretical literature discussed in this paper. ${ }^{18}$ It may therefore not come as a surprise that such groups have thus far been no more effective in advancing emissions reductions than the UNFCCC has been. For example, Andresen (2014) evaluates select "exclusive alternatives" to the UNFCCC, such as the AsiaPacific Partnership on Clean Development and Climate Change, the Major Economies Forum on Energy and Climate, the G20, and the Climate and Clean Air Coalition. He concludes that these alternatives have largely served as "discussion clubs" that have achieved very little in terms of actual emissions reductions. ${ }^{19}$ Similarly, after considering no fewer than 17 climate clubs, Weischer et al. (2012) conclude that these clubs constitute little more than forums for political dialogue. ${ }^{20}$

In assessing the overall achievements of a climate club, we have to determine also its impact (if any) on non-members and on important international institutions, in particular the UNFCCC. Two main subcategories of non-members may be distinguished: those who share club members' concern with climate change but do not find membership conditions attractive (or are not invited to join), and those who fear that more ambitious mitigation measures could significantly hurt their own economies. Positive responses in the form of upgrading one's own commitments will likely be found only in the former subcategory and hardly match those of club members. Although most often assessed in terms of their own achievements only, climate clubs might interact synergistically with the UNFCCC (Weischer et al., 2012). By capturing the attention of governments, news media and stakeholders for at least a couple of weeks, major UNFCCC conferences, such as COP 21, can generate additional incentives for governments and delegations to perform well in the eyes of domestic constituencies and other important stakeholders. In such a setting, frontrunners will have an advantage over laggards, and club members might use that advantage to link up with likeminded non-members and form a broader coalition of "pushers". Such a move will hardly suffice to radically change the negotiation game, but the possibility of synergistic interaction indicates that some climate clubs can make a difference also beyond the impact of the mitigation measures undertaken by its own members.

\section{Final remarks}

Although the scholarly literature on climate clubs is growing, scholars are still relatively early in the process of trying to understand the potential of climate clubs for being instrumental in mitigating climate change. Because effective climate clubs do not (yet) exist, simulation models and other formal models will likely continue to play an important role in moving this process forward. We therefore end by offering a few recommendations concerning how future research based on such models might further enhance our knowledge about climate clubs and climate change mitigation.

First, our own papers reviewed in the Section "The emergence of effective climate clubs: some lessons from formal models" omit trade sanctions as an instrument for generating club growth. In contrast, using a game-theoretic model, Nordhaus (2015) finds that carbon pricing combined with import tariffs can produce high levels of participation and abatement. Notably, however, he conceives of clubs as a top-down approach, where the regime is designed before countries decide whether to participate. Thus, his conception of clubs differs from ours, in which starting with a small group of actors constitutes a defining feature. Nordhaus (2015: 1352) is agnostic about the process of establishing and ensuring club growth. More research is needed to determine whether a threat of trade sanctions by a small group of initiators might suffice to facilitate club growth in the top-down type of club he considers. Concerning bottom-up clubs, it seems plausible that such a threat can motivate reluctant countries to join, considering that positive trade measures (a credible promise of preferential market access) has a similar effect (Hovi et al., 2015).

Second, technological development has also been proposed as an instrument for broadening participation in climate regimes (for example, Stewart et al., 2013a; Urpelainen, 2013). Formal modelling may provide insights into the conditions under which this instrument might be successful. A particularly interesting design challenge concerns the optimal strength of intellectual property rights.

Third, some climate club proposals envision participation by state and non-state actors alike (Stewart et al., 2013a,b). A limitation of extant formal models in this field concerns their exclusive focus on states (including groups of states such as the EU). Thus, extending extant formal models to include non-state actors constitutes yet another challenge for future research.

Finally, a second (yet related) limitation of extant formal models of climate clubs is that they treat states as unitary actors. Although a useful simplification, this approach overlooks that some of the greatest impediments to international cooperation derive from the interaction between domestic and international political processes (Putnam, 1988; Mayer, 1992; Wangler et al., 2013). Adding a domestic level to formal climate club models might capture some of these impediments and might also enable incorporation of sub-national actors, such as city governments and regional authorities that are currently playing an increasingly important role in international climate politics.

\section{Notes}

1 See, for example, Eckersley (2012).

2 Pol et al. (2012) show that even a limited degree of altruism can stabilize the grand coalition in a standard two-stage coalition model. In their model, only a small number of countries will participate if all countries are exclusively motivated by selfinterest.

3 Certain paragraphs in this section draw extensively and, sometimes, verbatim on Hovi et al. (2015).

4 The possibility of organizing clubs inside the UNFCCC raises questions concerning differentiation, akin to those found in the EU. See Harstad (2006) and Weikard et al. (2015) for interesting attempts to map the conditions under which "inner clubs" may 
enhance efficiency, including the effect of heterogeneity, the size of externalities, and the role of mandatory and minimum participation rules. At the 2009 Conference of the Parties at Copenhagen, an attempt by the Danish presidency to broker a deal among a limited number of countries outside the usual UNFCCCC preparatory meetings was eventually condemned as "undemocratic and unfair" (For example, see McGee, 2011).

5 See Sandler (2013: 265).

6 Green (2015) considers a third type-pseudo-clubs-characterized by fluid membership, small benefits and debatable excludability of benefits.

7 A preferential trade agreement for club members might serve as an example of a club good that can scale up with club size.

8 Stewart et al. (2013a, b) present climate clubs as one of three building blocks in their proposed new strategy for global climate change mitigation.

9 See Folmer et al. (1993) for an early treatment of the prospects for environmental cooperation based on issue linkage. Finus (2003) provides a very helpful review of the literature. Kemfert (2004) shows that linkage might incentivize nonparticipating countries to join a coalition.

10 Keohane et al. (2015) offer a list of potential benefits from linking emissions trading systems. These benefits include (but are not restricted to) lower abatement costs, greater price stability for permits, greater market liquidity, and reputation effects.

11 Green (2015) mentions the ISO 14001 standard as an example of a voluntary club. Third-party auditing ensures that the reputational benefit is restricted to firms that comply with the standard. It is not obvious that similar examples exist for clubs having countries as members.

12 See also our discussion about unilateral action and non-reciprocity vs. reciprocity in the Section "The empirical record of climate clubs and club-like arrangements".

13 Note that Young describes leadership as performed by individuals rather than by states. The basic mechanisms involved are nevertheless similar.

14 Brazil, India, China and South Africa.

15 BASIC countries plus Russia.

16 The exception concerns a coalition initiated by China alone.

17 This result echoes the findings reported by Weikard (2011).

18 Nevertheless, scholars occasionally use the term club when referring to such groups. For example, see Karlsson-Vinkhuyzen and van Asselt's (2009) introduction to the 2009 special issue on the APP in the journal International Environmental Agreements.

19 In the case of the APP, lack of funding contributed to the demise of the club. We thank an anonymous reviewer for pointing this out to us.

$20 \mathrm{Had}$ this review instead focused on IGOs (including IGOs established primarily for other purposes) some interesting success stories would have been found-one of them involving what is now the EU.

\section{References}

Andresen S (2014) Exclusive approaches to climate governance: More effective than the UNFCCC? In: Cherry TL, Hovi J and McEvoy DM (eds) Toward a New Climate Agreement. Routledge: London.

Asheim GB, Froyn CB, Hovi J and Menz F (2006) Regional versus global cooperation for climate control. Journal of Environmental Economics and Management; 51 (1): 93-109.

Barrett S (2003) Environment and Statecraft: The Strategy of Environmental TreatyMaking. Oxford University Press: Oxford.

Brewer TL (2015) Arctic Black Carbon from Shipping-A Club Approach to Climate-and-Trade Governance. International Centre for Trade and Sustainable Development: Geneva, Switzerland.

Buchanan JM (1965) An economic theory of clubs. Economica; 32 (1): 1-14.

Buchner B, Carraro C, Cersosimo I, Marchiori C (2005) Back to Kyoto? US participation and the linkage between R\&D and climate cooperation. In: Haurie A and Viguier L (eds) The Coupling of Climate and Economic Dynamics: Essays on Integrated Assessment. Springer Verlag: Berlin, Germany, pp 173-204.

Buchholz W, Haslbeck C and Sandler T (1998) When does partial participation pay? Finanzarchiv; 55 (1): 1-20.

Carraro C (ed) (1999) The structure of international agreements on climate change In: International Environmental Agreements on Climate Change. Kluwer Academic Publishers: Dordrecht, The Netherlands, pp 9-25.

Carraro C, Siniscalco D (1997) R\&D cooperation and the stability of international environmental agreements. In: Carraro C (ed) International Environmental Agreements: Strategic Policy Issues. Edward Elgar: Cheltenham, UK.

Cornes R and Sandler T (1986) The Theory of Externalities, Public Goods, and Club Goods. Cambridge University Press: New York.

Eckersley R (2012) Moving forward in the climate negotiations: Multilateralism or minilateralism? Global Environmental Politics; 12 (2): 24-45.

Falkner R (2015) A minilateral solution for global climate change? On bargaining efficiency, club benefits and international legitimacy. Centre for Climate Change. Economics and Policy. Working Paper No. 222, London, UK.

Finus M (2003) Stability and design of international environmental agreements: The case of transboundary pollution. In: Folmer $\mathrm{H}$ and Tietenberg $\mathrm{T}$ (eds) The International Yearbook of Environmental and Resource Economics 2003/2004: A Survey of Current Issues. Edward Elgar: Cheltenham, UK, pp 82-158.
Finus M, Rundshagen B (2003) Endogenous coalition formation in global pollution control: A partition function approach. In: Carraro C (ed) Endogenous Formation of Economic Coalitions. Edward Elgar: Cheltenham, UK, pp 156-198.

Finus M, van Ierland E and Dellink R (2006) Stability of climate coalitions in a Cartel formation game. Economics of Governance; 7 (3): 271-291.

Folmer H, Mouche P v and Ragland S (1993) Interconnected games and international environmental problems. Environmental and Resource Economics; 3 (4): 313-335.

Fraser CD and Hollander A (1992) On Membership in Clubs. Warwick Economic Research Papers No. 346, Warwick, UK.

Green JF (2015) The strength of weakness: Pseudo-clubs in the climate regime. Climatic Change; 1-12, online first 25 August 2015.

Hannam P, Vasconcelos V, Levin S and Pacheco J (2015) Incomplete cooperation and co-benefits: Deepening climate cooperation with a proliferation of small agreements. Climatic Change; 1-15, online first 30 September 2015.

Harstad B (2006) Flexible integration? Mandatory and minimum participation rules. Scandinavian Journal of Economics; 108 (4): 683-702.

Helsley RW and Strange WC (1991) Exclusion and the theory of clubs. Canadian Journal of Economics; 24 (4): 888-899.

Hoel M (1991) Global environmental problems: The effects of unilateral actions taken by one country. Journal of Environmental Economics and Management; 20 (1): 55-70.

Holtsmark B (2013) International cooperation on climate change: Why is there so little progress? In: Fouquet R (ed) Handbook on Energy and Climate Change. Edward Elgar: Cheltenham, UK, pp 327-343.

Hovi J, Skodvin T and Aakre S (2013) Can climate change negotiations succeed? Politics and Governance; 1 (2): 138-150.

Hovi J and Sprinz DF (2006) The limits of the least ambitious program. Global Environmental Politics; 6 (3): 28-42.

Hovi J, Sprinz D, Sælen H and Underdal A (2015) Climate Clubs: A Gateway to Effective Climate Cooperation? Oslo, Norway: Paper presented to the annual Convention of the International Studies Association 2015, http://www.google. no/url? sa $=\mathrm{t} \& \mathrm{rct}=\mathrm{j} \& \mathrm{q}=\&$ esrc $=\mathrm{s} \&$ source $=$ web $\& \mathrm{~cd}=4 \& \mathrm{ved}=0$ ahUKEwiardK NzvflAhVsGZoKHawhB3UQFgg0MAM\&url = http\%3A\%2F\%2F www.bath.ac. uk\%2Fipr\%2Fpdf\%2Fevents\%2Fclimate-change\%2FHovi.pdf\&usg = AFQjCNG aZD_eDaIp5KGhmyYtKfC86hy9aQ.

Karlsson-Vinkhuyzen S and van Asselt H (2009) Introduction: Exploring and explaining the Asia-Pacific partnership on clean development and climate. International Environmental Agreements; 9 (3): 195-211.

Kemfert C (2004) Climate coalitions and international trade: Assessment of cooperation incentives by issue linkage. Energy Policy; 32 (4): 455-465.

Keohane N, Petsonk A and Hanafi A (2015) Toward a club of carbon markets. Climatic Change; 1-15, online first 15 October 2015.

Knight FH (1924) Some fallacies in the interpretation of social cost. Quarterly Journal of Economics; 53 (4): 123-129.

Leycegu B and Rammirez I (2015) A WTO Exception to Incorporate Climate Clubs. International Centre for Trade and Sustainable Development (ICTSD) and Word Economic Forum: Geneva, Switzerland.

Mayer FW (1992) Managing domestic differences in international negotiations: The strategic use of internal side-payments. International Organization; 46 (4): 793-818.

McGee JS (2011) Exclusive minilateralism: An emerging discourse within international climate change governance. PORTAL Journal of Multidisciplinary International Studies; 8 (3): 1-29.

Nordhaus W (2015) Climate clubs: Overcoming free-riding in international climate policy. American Economic Review; 105 (4): 1339-1370.

Olson M Jr (1965) The Logic of Collective Action. Harvard University Press: Cambridge, MA.

Ostrom E, Gardner R and Walker J (1994) Rules, Games and Common-Pool Resources. The University of Michigan Press: Ann Arbor, MI.

Pachauri RK et al (2014) India-California Air Pollution Mitigation Program. Joint Initiative by the Energy and Resources Institute (TERI), University of California at San Diego, and the California Air Resources Board, Knowledge to Action Plan, Report to the World Bank, http://www-ramanathan.ucsd.edu/about/ icamp/KAP_JAN_30_full_text.pdf.

Pigou AC (1920) The Economics of Welfare. Palgrave MacMillan: London.

Pol T van der, Weikard H-P and van Ierland E (2012) Can altruism stabilize international climate agreements? Ecological Economics; 81 (September): $112-120$.

Prakash A and Potoski M (2007) Collective action theory through voluntary environmental programs: A club theory perspective. The Policy Studies Journal; 35 (4): 773-792.

Putnam RD (1988) Diplomacy and domestic politics: The logic of two-level games. International Organization; 42 (3): 427-460.

Rossi C (2014) Introducing public-private technology pools to address climate change. In: de Conick H, Lorch R and Sagar AD (eds) The Way Forward in International Climate Policy. Climate and Development Knowledge Network: London, UK, pp 37-43. 
Sandler T (2013) Buchanan clubs. Constitutional Political Economy; 24 (4): 265-284.

Sandler T, Sterbenz FP and Tschirhart J (1985) Uncertainty and clubs. Economica; 52 (4): 467-477.

Sprinz DF and Vaahtoranta T (1994) The interest-based explanation of international environmental policy. International Organization; 48 (1): 77-105.

Stewart RB, Oppenheimer M and Rudyk B (2013a) Building blocks for global climate protection. Stanford Environmental Law Journal; 32 (2): 12-43.

Stewart RB, Oppenheimer M and Rudyk B (2013b) A new strategy for global climate protection. Climatic Change; 120 (1-2): 1-12.

Sælen H (2015) Side-payments: An effective instrument for building climate clubs? International Environmental Agreements; 1-20, online first 24 October 2015.

Tiebout CM (1956) A pure theory of local expenditures. Journal of Political Economy; 64 (5): 416-424.

Underdal A (1980) The Politics of International Fisheries Management. The Case of the North-East Atlantic. Oslo University Press: Oslo, Norway.

Underdal A (1994) Leadership theory-Rediscovering the arts of management. In: Zartman IW (ed) International Multilateral Negotiation: Approaches to the Management of Complexity. Jossey-Bass: San Francisco, CA, pp 178-197.

Underdal A (ed) (1998) Introduction. In: The Politics of International Environmental Management. Kluwer: Dordrecht, The Netherlands, pp 1-12.

Underdal A, Hovi J, Kallbekken S and Skodvin T (2012) Can conditional commitments break the climate change negotiations deadlock? International Political Science Review; 33 (4): 475-493.

UNFCCC. (2009) Decisions 2/CP.15: The Copenhagen Accord, http://unfccc.int/ resource/docs/2009/cop15/eng/11a01.pdf\#page $=4$.

Urpelainen J (2013) Can strategic technology development improve climate cooperation? A game-theoretic analysis. Mitigation and Adaptation Strategies for Global Change; 18 (6): 785-800.

Victor D G (2011) Global Warming Gridlock: Creating More Effective Strategies for Protecting the Planet. Cambridge University Press: Cambridge, UK.

Victor D G (2015) The Case for Climate Clubs. International Centre for Trade and Sustainable Development (ICTSD) and World Economic Forum: Geneva, Switzerland.

Wangler L, Altamirano-Cabrera J-C and Weikard H-P (2013) The political economy of international environmental agreements: A survey. International Environmental Agreements; 13 (3): 387-403.

Weikard H- P (2011) Toward a global climate constitution In: Held M, Kubon-Gilke G and Sturn R (eds) Institutionen ökologischer Nachhaltigkeit.
Normative und institutionelle Grundfragen der Ökonomik; Jahrbuch 9 Metropolis: Marburg, Germany, pp 89-106.

Weikard H-P, Wangler L and Freytag A (2015) Minimum participation rules with heterogenous countries. Environmental and Resource Economics; 62 (4): 711-727.

Weischer L, Morgan J and Patel M (2012) Climate clubs: Can small groups of countries make a big difference in addressing climate change? Review of European Community and International Environmental Law (RECIEL); 21 (3): 177-192.

Wiseman J (1957) The theory of public utility price-An empty box. Oxford Economic Papers; 9 (1): 56-74.

Young OR (1991) Political leadership and regime formation: On the development of institutions in international society. International Organization; 45 (3): 281-308.

\section{Data Availability}

Data sharing is not applicable to this article as no datasets were generated or analysed during the current study.

\section{Acknowledgements}

Sælen and Underdal gratefully acknowledge financial support from the Research Council of Norway (grant no. 209701 for CICEP).

\section{Additional Information}

Competing interests: The authors declare no competing financial interests.

Reprints and permission information is available at http://www.palgrave-journals.com/ pal/authors/rights_and_permissions.html

How to cite this article: Hovi J, Sprinz DF, Sælen H and Underdal A (2016) Climate change mitigation: a role for climate clubs? Palgrave Communications. 2:16020 doi: 10.1057/palcomms.2016.20.

(c) (i) This work is licensed under a Creative Commons Attribution 4.0 article are included in the article's Creative Commons license, unless indicated otherwise in the credit line; if the material is not included under the Creative Commons license, users will need to obtain permission from the license holder to reproduce the material. To view a copy of this license, visit http://creativecommons.org/licenses/by/4.0/ 